\title{
Iron-Catalyzed Cross-Coupling of Imidoyl Chlorides with Grignard Reagents
}

Lars K. Ottesen, Fredrik Ek, and Roger Olsson*

\section{SUPPORTING INFORMATION}




\section{Table of Contents}

Supporting information file one(this file)

General experimental paragraph

Experimental details

Supporting information file two

${ }^{13}$ C NMR

Supporting information file three
S3

S3-S15

S16-S38

${ }^{1}$ H NMR

S39-S61 
General Information. ${ }^{1} \mathrm{H}$ NMR and ${ }^{13} \mathrm{C}$ NMR spectra were recorded on a Varian mercury $400 \mathrm{VX}$ $\left({ }^{1} \mathrm{H}-\mathrm{NMR}\right.$ at $400 \mathrm{MHz}$ and ${ }^{13} \mathrm{C}-\mathrm{NMR}$ at $\left.100 \mathrm{MHz}\right)$ spectrometer with solvent resonance as the internal standard: $\mathrm{CDCl}_{3}\left(\delta_{\mathrm{H}}: 7.26, \delta_{\mathrm{C}}: 77.16\right)$; DMSO-d $\mathrm{d}_{6}:\left(\delta_{\mathrm{H}}: 2.50, \delta_{\mathrm{C}}: 39.52\right)$; Acetone-d $\mathrm{d}_{6}:\left(\delta_{\mathrm{H}}\right.$ : $\left.2.05, \delta_{\mathrm{C}}: 29.84 ; 206.26\right)$ and $\mathrm{MeOH}-\mathrm{d}_{4}\left(\delta_{\mathrm{H}}: 3.31, \delta_{\mathrm{C}}: 49.00\right){ }^{1} \mathrm{H} \mathrm{NMR}$ are reported as follows: chemical shifts in ppm, multiplicity $(\mathrm{s}=$ singlet, br $\mathrm{s}=$ broad singlet, $\mathrm{d}=$ doublet, $\mathrm{dd}=$ double doublet, $\mathrm{t}=$ triplet, $\mathrm{tt}=$ triple triplet, $\mathrm{m}=$ multiplet). The microwave-assisted reactions were carried out using a SmithCreator ${ }^{\mathrm{TM}}$ single mode cavity; producing continuous irradiation at $2450 \mathrm{MHz}$. Reaction temperature and pressure were determined using the build in, on-line IR-and pressure sensors. Analytical thin layer chromatography (TLC) was performed on Silica gel $60 \mathrm{~F}_{254}$. Visualization was accomplished with UV light. Purification of the reaction products was carried out by column chromatography using $\mathrm{SiO}_{2}(60 \AA$, $200 \mu)$. Melting points were optained using SMP3 Melting Point Apparatus with an open capillary tube and are uncorrected. HRMS analyses were recorded in $\mathrm{FAB}(+)$ mode using direct inlet. Unless otherwise noted, all reagents were obtained from commercial sources and used without further purification.

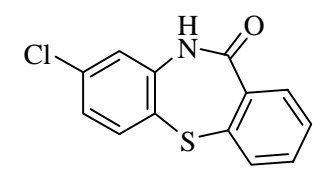

8-chloro-10H-dibenzo[b,f][1,4]thiazepin-11-one: $\mathrm{Cs}_{2} \mathrm{CO}_{3}(7.43 \mathrm{~g}, 23 \mathrm{mmol})$ was added to a solution of 4-chloro-1-fluoro-2-nitrobenzene (2.00 g, $11 \mathrm{mmol})$ and methyl 2-mercaptobenzoate $(3.13 \mathrm{ml}, 23 \mathrm{mmol})$ in DMF $(25 \mathrm{ml})$ and the resulting mixture was stirred for 2 hours at $40{ }^{\circ} \mathrm{C}$. The reaction mixture was then cooled to room temperature and diluted with DCM $(60 \mathrm{ml})$. The organic phase was washed with water and dried $\left(\mathrm{Na}_{2} \mathrm{SO}_{4}\right)$. Filtration, removal of the solvent at reduced pressure gave $2.6 \mathrm{~g}(73 \%)$ of the crude product, which was sufficiently pure to be used in the next step without further purification. The crude product $(2.6 \mathrm{~g}, 8.0 \mathrm{mmol})$ was dissolved in THF $(15 \mathrm{ml})$ and $2 \mathrm{M} \mathrm{LiOH}(40 \mathrm{mmol})$ and stirred at $60{ }^{\circ} \mathrm{C}$ for 2 hours and then allowed to cool to room temperature. THF was removed at reduced pressure and the aqueous mixture was acidified with $\mathrm{HCl}(2 \mathrm{M})$ until $\mathrm{pH} 2$. The precipitation was filtered off, washed with $0.1 \mathrm{M} \mathrm{NaOH}$ solution and finally dried to give the crude product $2.3 \mathrm{~g}(93 \%) . \mathrm{Na}_{2} \mathrm{~S}_{2} \mathrm{O}_{4}(37 \mathrm{mmol})$ was added to a solution of the crude product $(2.3 \mathrm{~g}, 7.4$ $\mathrm{mmol})$ in $2 \mathrm{M} \mathrm{K}_{2} \mathrm{CO}_{3}(35 \mathrm{mmol})$ and $\mathrm{EtOH}(20 \mathrm{ml})$ and the reaction was stirred at room temperature for $15 \mathrm{~min}$. EtOH was removed at reduced pressure and the resulting aqueous mixture was acidified with $\mathrm{HCl}(2 \mathrm{M})$ until $\mathrm{pH} 2$ and poured into ethyl acetate. The organic layer was washed with water, brine, dried $\left(\mathrm{Na}_{2} \mathrm{SO}_{4}\right)$, filtered and evaporated to give the crude product $1.2 \mathrm{~g}(61 \%)$. Finally, the crude product (1.2 g, $4.3 \mathrm{mmol})$, EDCI (1.24 g, $6.5 \mathrm{mmol})$, HOBt (878 mg, $6.5 \mathrm{mmol})$, DMAP (5 $\mathrm{mg}, 0.04 \mathrm{mmol})$ and TEA $(19.3 \mathrm{mmol})$ in $\mathrm{MeCN}(8 \mathrm{ml})$ was heated in microwave at $140{ }^{\circ} \mathrm{C}$ for 10 
min. The reaction mixture was cooled to room temperature, diluted with water and acidified with $\mathrm{HCl}(2 \mathrm{M})$ until $\mathrm{pH}$ 2. The precipitation was filtered off, washed with $0.1 \mathrm{M} \mathrm{NaOH}$ solution and dried to give $572 \mathrm{mg}(51 \%)$ of the title compound as a white powder, which was sufficiently pure to be used without further purification. M.p. $295-300^{\circ} \mathrm{C}$; Litt. $290{ }^{\circ} \mathrm{C}$ (Collect Czech. Chem. Commun. 1959, 24, 207-211).

${ }^{1} \mathrm{H}$ NMR (400 MHz, DMSO-d $) \delta 10.72$ (br s, 1H,), $7.68(\mathrm{~m}, 1 \mathrm{H}), 7.51(\mathrm{~m}, 4 \mathrm{H}), 7.28(\mathrm{~d}, 1 \mathrm{H}, J=2.4$ $\mathrm{Hz}), 7.20(\mathrm{dd}, 1 \mathrm{H}, J=8.4,2.4 \mathrm{~Hz}) ;{ }^{13} \mathrm{C} \mathrm{NMR}\left(100 \mathrm{MHz}, \mathrm{DMSO}-\mathrm{d}_{6}\right) \delta 168.9,142.0,138.3,136.3$, 134.6 (2C), 133.0, 132.1 (2C), 129.9, 128.4, 125.8, 123.3.

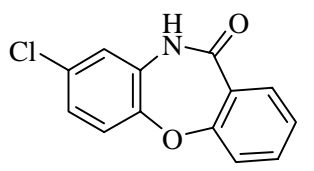

8-Chloro-10H-dibenzo[b,1][1,4]oxazepin-11-one: $\mathrm{Cs}_{2} \mathrm{CO}_{3}(7.43 \mathrm{~g}, 23 \mathrm{mmol})$ was added to a solution of 4-chloro-1-fluoro-2-nitrobenzene (2.00 g, $11 \mathrm{mmol})$ and methyl salicylate $(2.92 \mathrm{ml}, 23 \mathrm{mmol})$ in DMF $(25 \mathrm{ml})$ and the resulting mixture was stirred for 2 hours at $60{ }^{\circ} \mathrm{C}$. The reaction mixture was cooled to room temperature and diluted with DCM $(60 \mathrm{ml})$. The organic phase was washed with water and then dried $\left(\mathrm{Na}_{2} \mathrm{SO}_{4}\right)$. Filtration, removal of the solvent at reduced pressure gave $2.80 \mathrm{~g}(80 \%)$ of the crude product, which was sufficiently pure to be used in the next step without further purification. The crude product (2.8 $\mathrm{g}, 9.55 \mathrm{mmol})$ was then dissolved in THF (15 ml) and $2 \mathrm{M} \mathrm{LiOH}(40 \mathrm{mmol})$ and stirred at $60{ }^{\circ} \mathrm{C}$ for $2 \mathrm{~h}$ and then allowed to cool to room temperature. THF was removed at reduced pressure and the aqueous mixture was acidified with $\mathrm{HCl}(2 \mathrm{M})$ until $\mathrm{pH}$ 2. The precipitation was filtered off, washed with $0.1 \mathrm{M} \mathrm{NaOH}$ solution and finally dried to give the crude product $2.4 \mathrm{~g}(86 \%) . \mathrm{Na}_{2} \mathrm{~S}_{2} \mathrm{O}_{4}(37$ mmol) was added to a solution of the crude product $(2.4 \mathrm{~g}, 8.2 \mathrm{mmol})$ in $2 \mathrm{M} \mathrm{K}_{2} \mathrm{CO}_{3}(41 \mathrm{mmol})$ and $\mathrm{EtOH}(20 \mathrm{ml})$ and the reaction was stirred at room temperature for $15 \mathrm{~min}$. EtOH was then removed at reduced pressure and the resulting aqueous mixture was acidified with $\mathrm{HCl}(2 \mathrm{M})$ until $\mathrm{pH} 2$ and poured into ethyl acetate. The organic layer was washed with water, brine, dried $\left(\mathrm{Na}_{2} \mathrm{SO}_{4}\right)$, filtered and evaporated to give the crude product $1.1 \mathrm{~g}$ (52\%). Finally, the crude product ( $1.1 \mathrm{~g}, 4.2 \mathrm{mmol})$, EDCI (1.20 g, $6.3 \mathrm{mmol})$, HOBt (851 mg, $6.3 \mathrm{mmol})$, DMAP (5 mg, $0.04 \mathrm{mmol})$ and TEA (18.9 $\mathrm{mmol}$ ) in $\mathrm{MeCN}(8 \mathrm{ml})$ was heated in microwave at $140{ }^{\circ} \mathrm{C}$ for $10 \mathrm{~min}$. The reaction mixture was cooled to room temperature, diluted with water and acidified with $\mathrm{HCl}(2 \mathrm{M})$ until $\mathrm{pH} 2$. The precipitation was filtered off, washed with $0.1 \mathrm{M} \mathrm{NaOH}$ solution and dried $\left(\mathrm{Na}_{2} \mathrm{SO}_{4}\right)$ to give 676 $\mathrm{mg}(66 \%)$ of the title compound as a white powder, which was sufficiently pure to be used without further purification. M.p. 255-258 ${ }^{\circ} \mathrm{C}$ (decomposition); Litt. 250-255 ${ }^{\circ} \mathrm{C}$ (Applied and Environmental Microbiology 1977, 33 (1), 26-30). 
${ }^{1} \mathrm{H}-\mathrm{NMR}\left(400 \mathrm{MHz}, \mathrm{DMSO}-\mathrm{d}_{6}\right) \delta 10.61(\mathrm{br} \mathrm{s}, 1 \mathrm{H}), 7.76(\mathrm{dd}, 1 \mathrm{H}, J=7.6,1.6 \mathrm{~Hz}), 7.64-7.58(\mathrm{~m}$, 1H), 7.38-7.28 (m, 3H), 7.20-7.12 (m, 2H); ${ }^{13} \mathrm{C}-\mathrm{NMR}$ (100 MHz, DMSO-d 6 ) $\delta 166.3,159.2,149.8$, $135.4,133.3,132.2,130.2,126.4,126.0,125.4,123.7,121.6,121.3$.

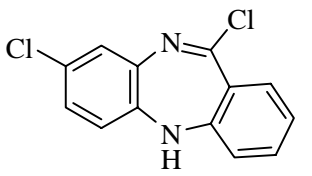

8,11-Dichloro- 5H-dibenzo[b,e][1,4]diazepine (8): A mixture of 8-Chloro11-oxo-10,11-dihydro-5H-dibenzo-1,4-diazepine $(2.90 \mathrm{~g}, 20 \mathrm{mmol})$, phosphorus oxychloride $(5.6 \mathrm{ml}, 60 \mathrm{mmol})$ and $\mathrm{N}$-dimethylaniline $(10.2 \mathrm{ml}, 80$ mmol) in toluene $(40 \mathrm{ml})$ was heated at $95{ }^{\circ} \mathrm{C}$ for 2 hours. The reaction mixture was then cooled to room temperature and excess of phosphorus oxychloride, $\mathrm{N}$-dimethylaniline and toluene was removed at reduced pressure. The resulting residue was then dissolved in dioxane $(20 \mathrm{ml})$ and $2 \mathrm{M}$ $\mathrm{Na}_{2} \mathrm{CO}_{3}(30 \mathrm{ml}, 0.06 \mathrm{~mol})$ and heated at $80{ }^{\circ} \mathrm{C}$ for 1 hour. The reaction mixture was cooled to room temperature and dioxane was removed at reduced pressure and the resulting aqueous solution was extracted with EtOAc $(30 \mathrm{ml})$. The organic phase was washed with water, brine and dried $\left(\mathrm{Na}_{2} \mathrm{SO}_{4}\right)$. Filtration, removal of the solvent at reduced pressure gave the crude product. Purification by column chromatography (EtOAc/heptane 1:4) afforded $3.76 \mathrm{~g}(72 \%)$ of the title compound as a yellow powder. M.p. $128-130{ }^{\circ} \mathrm{C}$.

${ }^{1} \mathrm{H}$ NMR $\left(400 \mathrm{MHz}, \mathrm{CDCl}_{3}\right) \delta 7.59(\mathrm{dd}, 1 \mathrm{H}, J=8.0,1.6 \mathrm{~Hz}), 7.31(1 \mathrm{H}, \mathrm{dt}, J=7.6,1.6 \mathrm{~Hz}), 7.15(\mathrm{~d}$, $1 \mathrm{H}, J=2.4 \mathrm{~Hz}), 7.04-7.00(\mathrm{~m}, 2 \mathrm{H}), 6.63(\mathrm{dd}, 1 \mathrm{H}, J=8.0,1.2 \mathrm{~Hz}), 6.58(\mathrm{~d}, 1 \mathrm{H}, J=8.4 \mathrm{~Hz}), 4.95$ $(1 \mathrm{H}$, br s $) ;{ }^{13} \mathrm{C}$ NMR $\left(100 \mathrm{MHz}, \mathrm{CDCl}_{3}\right) \delta 157.2,152.1,140.3,138.3,134.1,132.0,129.8,128.6$, 128.1, 127.1, 123.6, 121.0, 119.8; HRMS (Ion Mode: $\mathrm{FAB}^{+}$) $\mathrm{m} / z$ [M] Calcd for $\mathrm{C}_{13} \mathrm{H}_{8} \mathrm{Cl}_{2} \mathrm{~N}_{2}$, 262.0065; Found, 262.0068.

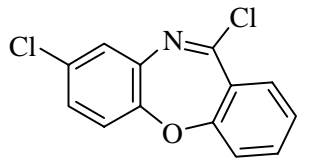

8,11-Dichlorodibenzo[b,f][1,4]oxazepine (9): 8-Chloro-10H-dibenzo [b,1] $[1,4]$ oxazepin-11-one $(490 \mathrm{mg}, 2.0 \mathrm{mmol})$ was heated in phosphorus oxychloride $(15 \mathrm{ml})$ at $95{ }^{\circ} \mathrm{C}$ for 2 hours. The reaction mixture was then cooled to room temperature and excess of phosphorus oxychloride was removed at reduced pressure. The resulting residue was dissolved in EtOAc $(30 \mathrm{ml})$ and the organic phase was washed with brine and dried $\left(\mathrm{Na}_{2} \mathrm{SO}_{4}\right)$. Filtration, removal of the solvent at reduced pressure gave the crude product. Purification by column chromatography (EtOAc/heptane 1:4) afforded $440 \mathrm{mg}(84 \%)$ as a white powder. M.p. 101-103 ${ }^{\circ} \mathrm{C}$; HRMS (Ion Mode: $\mathrm{FAB}^{+}$) $\mathrm{m} / \mathrm{z}\left[\mathrm{M}+\mathrm{H}^{+}\right]$Calcd for $\mathrm{C}_{13} \mathrm{H}_{7} \mathrm{Cl}_{2} \mathrm{NO}_{2}$, 263.9983; Found, 263.9993. 
${ }^{1} \mathrm{H}$ NMR (400 MHz, acetone-d $\left.{ }_{6}\right) \delta 7.82(\mathrm{dd}, 1 \mathrm{H}, J=7.6,1.6 \mathrm{~Hz}), 7.72-7.67(\mathrm{~m}, 1 \mathrm{H})$ 7.43-7.39 (m, $1 \mathrm{H}), 7.36-7.29(\mathrm{~m}, 4 \mathrm{H}) ;{ }^{13} \mathrm{C} \mathrm{NMR}(100 \mathrm{MHz}$, acetone-d 6$) \delta 160.1,155.3,150.5,139.2,135.7$, 130.9, 130.6, 129.0, 127.3, 127.1, 126.3, 122.9, 121.3.

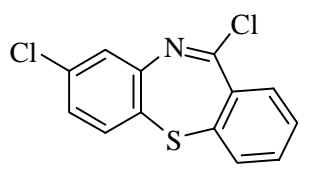

8,11-Dichloro-dibenzo [b,f] $[\mathbf{1 , 4}]$ thiazepine (10): 8-Chloro-10H-dibenzo $[\mathrm{b}, \mathrm{f}][1,4]$ thiazepin-11-one (500 $\mathrm{mg}, 1.92 \mathrm{mmol})$ was heated in phosphorus oxychloride $(15 \mathrm{ml})$ at $95{ }^{\circ} \mathrm{C}$ for 2 hours. The reaction mixture was then cooled to room temperature and excess of phosphorus oxychloride was removed at reduced pressure. The resulting residue was dissolved in EtOAc $(30 \mathrm{ml})$ and the organic phase was washed with brine and dried $\left(\mathrm{Na}_{2} \mathrm{SO}_{4}\right)$. Filtration, removal of the solvent at reduced pressure gave the crude product. Purification by column chromatography (EtOAc/heptane 1:4) afforded $395 \mathrm{mg}$ (74\%) of the title compound as a white powder. M.p. $120-124{ }^{\circ} \mathrm{C}$; Litt. $118-119{ }^{\circ} \mathrm{C}$ (Helv. Chim. Acta 1967, $50,245-254)$.

${ }^{1} \mathrm{H}$ NMR $\left(400 \mathrm{MHz}, \mathrm{CDCl}_{3}\right) \delta 7.74(\mathrm{~d}, 1 \mathrm{H}, J=8.0 \mathrm{~Hz}), 7.45-7.36(\mathrm{~m}, 4 \mathrm{H}), 7.28-7.26(\mathrm{~m}, 1 \mathrm{H}), 7.15-$ $7.12(\mathrm{~m}, 1 \mathrm{H}) ;{ }^{13} \mathrm{C}$ NMR $\left(100 \mathrm{MHz}, \mathrm{CDCl}_{3}\right) \delta 156.4,147.1,138.7,137.9,135.4,133.6,133.0$, $132.2,130.1,129.0,127.4,126.4,125.7$.

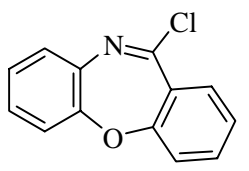

11-Chloro-dibenzo[b,f][1,4] oxazepine (1): 10H-Dibenzo[b,f][1,4] oxazepine-11one (500 mg, $2.37 \mathrm{mmol})$ was added phosphorus oxychloride $(20 \mathrm{ml})$ and heated at $95{ }^{\circ} \mathrm{C}$ for 2 hours. The reaction mixture was then cooled to room temperature and excess of phosphorus oxychloride was removed at reduced pressure. The resulting residue was dissolved in EtOAc $(25 \mathrm{ml})$ and the organic phase was washed with brine and dried $\left(\mathrm{Na}_{2} \mathrm{SO}_{4}\right)$. Filtration, removal of the solvent at reduced pressure gave the crude product. Purification by column chromatography (EtOAc/Heptane 1:4) afforded $424 \mathrm{mg}(78 \%)$ of the title compound as an oil, which solidifies on standing at $5{ }^{\circ} \mathrm{C}$. M.p. 53-55; Litt. 53-55 ${ }^{\circ} \mathrm{C}$ (US 4002639).

${ }^{1} \mathrm{H}$ NMR $\left(400 \mathrm{MHz}, \mathrm{CDCl}_{3}\right) \delta 7.75(\mathrm{dd}, 1 \mathrm{H}, J=2 \mathrm{~Hz}), 7.54-7.50(\mathrm{~m}, 1 \mathrm{H}), 7.35-7.32(\mathrm{~m}, 1 \mathrm{H}), 7.27-$ $7.23(\mathrm{~m}, 2 \mathrm{H}), 7.21-7.16(\mathrm{~m}, 3 \mathrm{H}) ;{ }^{13} \mathrm{C} \mathrm{NMR}\left(100 \mathrm{MHz}, \mathrm{CDCl}_{3}\right) \delta 160.3,154.2,151,6,138.2,134.7$, $130.6,129.1,128.2,127.4,126.1,125.5,121.3,121$.

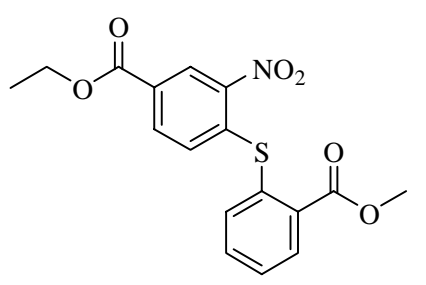

4-(2-Methoxycarbonyl-phenylsulfanyl)-3-nitro-benzoic acid ethyl ester: $\mathrm{Cs}_{2} \mathrm{CO}_{3}(10.06 \mathrm{~g}, 30.9 \mathrm{mmol})$ was added to a solution of ethyl 4flouro-3-nitrobenzoate $(6.60 \mathrm{~g}, \quad 30.9 \mathrm{mmol})$ and methyl 2- 
mercaptobenzoate $(4.67 \mathrm{ml}, 34 \mathrm{mmol})$ in DMF $(60 \mathrm{ml})$ and the resulting mixture was stirred for 2 hours at $40{ }^{\circ} \mathrm{C}$. The reaction mixture was cooled to room temperature and diluted with DCM (60 $\mathrm{ml})$. The organic phase was washed with water and dried $\left(\mathrm{Na}_{2} \mathrm{SO}_{4}\right)$. Filtration, removal of the solvent at reduced pressure and column chromatography (ethyl acetate/heptane 1:4) gave a yellow crystalline residue. Recrystallization from EtOAc-heptane gave $10.3 \mathrm{~g}(92 \%)$ of the title compound as yellow crystals. M.p. $117-119^{\circ} \mathrm{C}$.

${ }^{1} \mathrm{H}$ NMR (400 MHz, $\left.\mathrm{CDCl}_{3}\right) \delta 8.82(\mathrm{~d}, 1 \mathrm{H}, J=1.9 \mathrm{~Hz}), 7.94(\mathrm{~m}, 2 \mathrm{H}), 7.62-7.57(\mathrm{~m}, 3 \mathrm{H}), 6.92(\mathrm{~d}$, $1 \mathrm{H}, J=8.6 \mathrm{~Hz}), 4.38(\mathrm{q}, 2 \mathrm{H}, J=7.2 \mathrm{~Hz}), 3.78(\mathrm{~s}, 3 \mathrm{H}), 1.38(\mathrm{t}, 3 \mathrm{H}, J=7.0 \mathrm{~Hz}) ;{ }^{13} \mathrm{C} \mathrm{NMR}(100$ $\left.\mathrm{MHz}, \mathrm{CDCl}_{3}\right): \delta 166.8,164.6,145.5,144.1,137.6,136.3,133.4,133.0,131.5,131.3,130.5,129.8$, 128.1, 126.9, 61.9, 52.7, 14.5; HRMS (Ion Mode: $\mathrm{FAB}^{+}$) $\mathrm{m} / z\left[\mathrm{M}+\mathrm{H}^{+}\right]$Calcd for $\mathrm{C}_{17} \mathrm{H}_{15} \mathrm{NO}_{6} \mathrm{~S}$, 362.0698; Found, 362.0701.

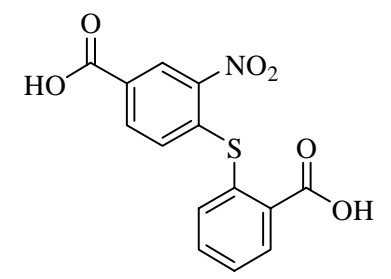

4-(2-Carboxy-phenylsulfanyl)-3-nitro-benzoicacid: 4-(2-Methoxy carbonyl-phenylsulfanyl)-3-nitro-benzoic acid ethyl ester (9.56 g, 26.5 mmol) dissolved in THF (570 ml) and aqueous $\mathrm{LiOH}(264 \mathrm{ml}, 1 \mathrm{M})$ was stirred at $60{ }^{\circ} \mathrm{C}$ for 2 hours and then allowed to cool to room temperature. $\mathrm{THF}$ was removed at reduced pressure and the remaining aquerous mixture was extracted once with EtOAc. $\mathrm{HCl}(2 \mathrm{M})$ was then added to the resulting solution until $\mathrm{pH}$ 2. The precipitation was filtered off, washed with water and finally dried, which afforded $8.7 \mathrm{~g}$ (99\%) of the title compound as yellow crystals. M.p. $250-253{ }^{\circ} \mathrm{C}$.

${ }^{1} \mathrm{H}$ NMR (400 MHz, methanol-d $\left.{ }_{4}\right) \delta 8.71(\mathrm{~d}, 1 \mathrm{H}, J=1.8 \mathrm{~Hz}), 7.95(\mathrm{~m}, 2 \mathrm{H}), 7.64-7.59(\mathrm{~m}, 3 \mathrm{H}), 7.00$ $(\mathrm{d}, 1 \mathrm{H}, J=8.6 \mathrm{~Hz}) ;{ }^{13} \mathrm{C}$ NMR $(100 \mathrm{MHz}$, methanol-d 4$) \delta 168.3,166.1,145.9,143.3,137.0,136.5$, 133.2, 132.6, 131.2, 131.1, 130.1, 130.0, 128.6, 126.3; HRMS (Ion Mode: $\mathrm{FAB}^{+}$) $m / z\left[\mathrm{M}+\mathrm{H}^{+}\right]$ Calcd for $\mathrm{C}_{14} \mathrm{H}_{9} \mathrm{NO}_{6} \mathrm{~S}, 320.0229$; Found, 320.0232 .

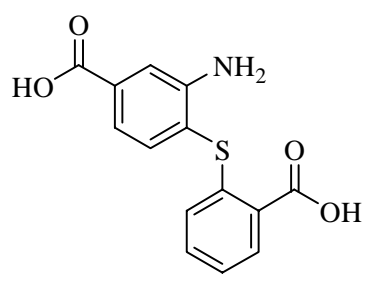

3-Amino-4-(2-carboxy-phenylsulfanyl)-benzoic acid: $\mathrm{Pd} / \mathrm{C}(10 \%, 200$ $\mathrm{mg})$ and $\mathrm{PtO}_{2}(100 \mathrm{mg})$ were added to 4-(2-carboxy-phenylsulfanyl)-3nitro-benzoicacid (2.9 g, $9.1 \mathrm{mmol}$ ) dissolved in $100 \mathrm{ml} \mathrm{MeOH}$. A balloon containing $\mathrm{H}_{2}$ was connected to the flask and the reaction flask was repeatedly evacuated and refilled with $\mathrm{H}_{2}$. After 16 hours the reaction mixture was filtered through a pad of celite, which then was washed carefully with $\mathrm{MeOH}$. Concentration of the filtrate at reduced pressure gave the crude product. Purification by 
recrystallization from EtOAc/MeOH afforded $2.3 \mathrm{~g}(88 \%)$ of the title compound as yellow crystals. M.p. $244-248^{\circ} \mathrm{C}$.

${ }^{1} \mathrm{H}$ NMR (400 MHz, methanol-d $\left.{ }_{4}\right) \delta 8.01(\mathrm{~d}, 1 \mathrm{H}, J=7.6 \mathrm{~Hz}), 7.51(\mathrm{~s}, 1 \mathrm{H}), 7.44(\mathrm{~d}, 1 \mathrm{H}, J=8.0 \mathrm{~Hz})$, $7.31(\mathrm{~d}, 1 \mathrm{H}, J=8.0 \mathrm{~Hz}), 7.28(\mathrm{t}, 1 \mathrm{H}, J=8.0 \mathrm{~Hz}), 7.16(\mathrm{t}, 1 \mathrm{H}, J=7.2 \mathrm{~Hz}), 6.74(\mathrm{~d}, 1 \mathrm{H}, J=8.0 \mathrm{~Hz})$; ${ }^{13} \mathrm{C}$ NMR (100 MHz, methanol-d 4 ): 169.8, 151.6, 141.6, 138.6 (2C), 134.7, 133.5, 132.7, 128.8, 127.2, 125.6, 119.9, 119.6, 117.3; HRMS (Ion Mode: $\mathrm{FAB}^{+}$) $m / z\left[\mathrm{M}+\mathrm{H}^{+}\right]$Calcd for $\mathrm{C}_{14} \mathrm{H}_{11} \mathrm{NO}_{4} \mathrm{~S}$, 290.0487 ; Found, 290.0487.

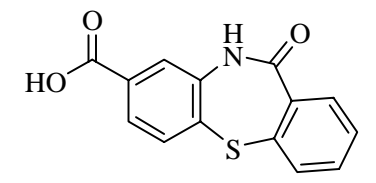

11-Oxo-10,11-dihydro-dibenzo $[\mathrm{b}, \mathrm{f}][1,4]$ thiazepine-8-carboxylic acid: CDI (4.53 g, $29 \mathrm{mmol})$ was added to 3-amino-4-(2-carboxyphenylsulfanyl)-benzoic acid $(2.1 \mathrm{~g}, 7.3 \mathrm{mmol})$ dissolved in THF (30 ml).

The reaction mixture was stirred for 16 hours at room temperature. Water $(200 \mathrm{ml})$ was then added to the reaction and the precipitant was filtered off and dried. Recrystallization from toluene gave $1.78 \mathrm{~g}(91 \%)$ of the title compound as a white solid. M.p. $330-335^{\circ} \mathrm{C}$.

${ }^{1} \mathrm{H}$ NMR (400 MHz, DMSO-d $\left.{ }_{6}\right) \delta 10.78$ (br s, 1H), 7.77 (s, 1H), 7.67 (m, 3H), 7.55-7.42 (m, 3H); ${ }^{13} \mathrm{C}$ NMR $\left(100 \mathrm{MHz}, \mathrm{DMSO}-\mathrm{d}_{6}\right) \delta 168.9,166.9,140.3,138.3,136.0,134.5,133.5,133.0,132.9$, 132.2, 132.1, 129.9, 126.5, 124.3; $\mathrm{MS}\left(\mathrm{ES}^{+}, \mathrm{M}+1\right): 272.4$.<smiles>O=C(Cl)c1ccc2c(c1)N=C(Cl)c1ccccc1S2</smiles>

\section{1-Chloro-dihydro-dibenzo $[\mathrm{b}, \mathbf{f}][1,4]$ thiazepine-8-carbonyl chloride:}

A solution of 11-oxo-10,11-dihydro-dibenzo[b,f][1,4]thiazepine-8carboxylic acid (200 $\mathrm{mg}, 0.74 \mathrm{mmol})$ and phosphorus pentachloride (756 $\mathrm{mg}, 3.68 \mathrm{mmol}$ ) in $4 \mathrm{ml}$ toluene was heated at $110{ }^{\circ} \mathrm{C}$ for 2 hours. Toluene and excess of phosphorus pentachloride were removed at reduced pressure to give $193 \mathrm{mg}(85 \%)$ of the title compound as a yellow solid, which was sufficiently pure to be used without further purification. M.p. $130-132{ }^{\circ} \mathrm{C}$.

${ }^{1} \mathrm{H}$ NMR $\left(400 \mathrm{MHz}, \mathrm{CDCl}_{3}\right) \delta 8.01(\mathrm{~d}, 1 \mathrm{H}, J=2.0 \mathrm{~Hz}), 7.87(\mathrm{dd}, 1 \mathrm{H}, J=8.4,2.2 \mathrm{~Hz}), 7.77(\mathrm{~m}$, $1 \mathrm{H}), 7.58(\mathrm{~d}, 1 \mathrm{H}, J=8.2 \mathrm{~Hz}), 7.47-7.44(\mathrm{~m}, 2 \mathrm{H}), 7.44-7.39(\mathrm{~m}, 1 \mathrm{H}) ;{ }^{13} \mathrm{C} \mathrm{NMR}\left(100 \mathrm{MHz}, \mathrm{CDCl}_{3}\right) \delta$ $167.5,157.1,146.7,137.8,137.4,136.3,134.5,133.4,133.3,132.6,130.3,129.5,129.1$, 128.8 .

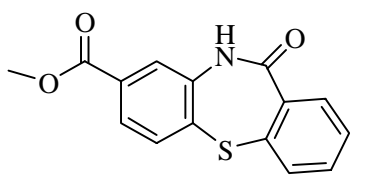

11-Oxo-10,11-dibenzo[b,f] $[1,4]$ thiazepine-8-carboxylic acid methyl ester: $\mathrm{Na}_{2} \mathrm{CO}_{3}(1.39 \mathrm{~g}, 13.05 \mathrm{mmol})$ was added to a solution of 11-oxo- 
10,11-dihydro-dibenzo [b,f][1,4] thiazepine-8-carboxylic acid (715 mg, $2.61 \mathrm{mmol})$ in DMF (20 $\mathrm{ml})$ and the reaction mixture was stirred for $30 \mathrm{~min}$ at room temperature. $\mathrm{CH}_{3} \mathrm{I}(0.81 \mathrm{ml}, 13.05$ mmol) was added and the two-phase mixture was stirred for 30 min. DMF was then removed at reduced pressure using an oil pump and the resulting residue was dissolved in EtOAc ( $25 \mathrm{ml})$. The organic phase was washed with saturated aqueous $\mathrm{NaHCO}_{3}$, brine and then dried $\left(\mathrm{Na}_{2} \mathrm{SO}_{4}\right)$. Filtration, removal of the solvent at reduced pressure gave the crude product. Purification by recrystallization from toluene afforded $640 \mathrm{mg}(86 \%)$ of the title compound as a white solid. M.p. $245-250{ }^{\circ} \mathrm{C}$.

${ }^{1} \mathrm{H}$ NMR (400 MHz, $\left.\mathrm{CDCl}_{3}\right) \delta 9.23$ (br s, 1H), 7.88-7.86 (m, 2H), 7.79-7.77 (m, 1H), $7.64(\mathrm{~d}, 1 \mathrm{H}, J$ $=8.0 \mathrm{~Hz}), 7.52-7.50(\mathrm{~m}, 1 \mathrm{H}), 7.45-7.38(\mathrm{~m}, 2 \mathrm{H}), 3.91(\mathrm{~s}, 3 \mathrm{H}) ;{ }^{13} \mathrm{C} \mathrm{NMR}\left(100 \mathrm{MHz}, \mathrm{CDCl}_{3}\right) \delta 169.4$, 165.9, 139.6, 136.8, 136.4, 135.8, 133.3, 132.7, 132.3, 132.2, 131.8, 129.3, 127.0, 123.7, 52.7; HRMS (Ion Mode: $\mathrm{FAB}^{+}$) $m / z\left[\mathrm{M}+\mathrm{H}^{+}\right]$Calcd for $\mathrm{C}_{14} \mathrm{H}_{11} \mathrm{NO}_{3} \mathrm{~S}, 286.0538$; Found, 286.0534.

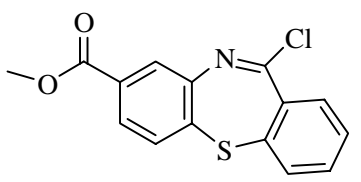

11-chloro-dibenzo[b,f][1,4]thiazepine-8-carboxylic acid methyl ester (14): A solution of 11-oxo-10,11-dibenzo[b,f][1,4]thiazepine-8-carboxylic acid methyl ester (540 mg, $1.89 \mathrm{mmol})$ and phosphorus pentachloride (1.97 $\mathrm{g}, 9.45 \mathrm{mmol}$ ) in $15 \mathrm{ml}$ toluene was heated at $110^{\circ} \mathrm{C}$ for 2 hours. Toluene and excess of phosphorus pentachloride were removed at reduced pressure. The resulting residue was dissolved in EtOAc (70 $\mathrm{ml})$ and the organic phase was washed with water, brine and then dried $\left(\mathrm{Na}_{2} \mathrm{SO}_{4}\right)$. Filtration, removal of the solvent at reduced pressure gave the crude product. Purification by column chromatography (EtOAc/heptane 1:4) afforded $410 \mathrm{mg}(71 \%)$ of the title compound as a yellow oil.

${ }^{1} \mathrm{H}$ NMR (400 MHz, $\left.\mathrm{CDCl}_{3}\right) \delta 7.86(\mathrm{dd}, 1 \mathrm{H}, J=2.0,0.4 \mathrm{~Hz}), 7.75(\mathrm{dd}, 1 \mathrm{H}, J=8.0,1.6 \mathrm{~Hz}), 7.69$ $7.67(\mathrm{~m}, 1 \mathrm{H}), 7.45(\mathrm{dd}, 1 \mathrm{H}, J=8.4,0.4 \mathrm{~Hz}), 7.40-7.32(\mathrm{~m}, 3 \mathrm{H}), 3.82(\mathrm{~s}, 3 \mathrm{H}) ;{ }^{13} \mathrm{C} \mathrm{NMR}(100 \mathrm{MHz}$, $\left.\mathrm{CDCl}_{3}\right) \delta 166.2,156.1,146.3,138.1,137.9,133.2,133.1,132.9,132.4,131.7,130.2,129.2,128.1$, 127.1, 52.6; HRMS (Ion Mode: $\mathrm{FAB}^{+}$) $\mathrm{m} / z\left[\mathrm{M}+\mathrm{H}^{+}\right]$Calcd for $\mathrm{C}_{15} \mathrm{H}_{10} \mathrm{ClNO}_{2} \mathrm{~S}, 304.0199$; Found, 304.0197.

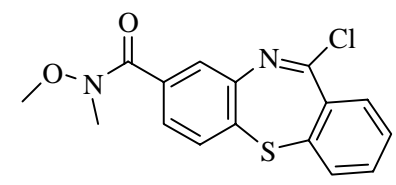

11-Chloro-dibenzo[b,f][1,4]thiazepine-8-carboxylic acid methoxymethyl-amide (16): A flame dried $10 \mathrm{ml}$ flask under argon was charged with 8,11-dichloro-dibenzo[b,f][1,4]thiazepine (622 mg, $2.0 \mathrm{mmol})$ in dry DCM (4 ml) and the resulting solution was then slowly added to a mixture of N,O- 
dimethylhydroxylamine hydrochloride $(388 \mathrm{mg}, 4.0 \mathrm{mmol})$ and TEA $(0.83 \mathrm{ml}, 6.0 \mathrm{mmol})$ in dry DCM $(6 \mathrm{ml})$. The resulting reaction mixture was stirred at room temperature for $30 \mathrm{~min}$ and then diluted with DCM $(20 \mathrm{ml})$. The organic phase was washed with water, brine and dried $\left(\mathrm{Na}_{2} \mathrm{SO}_{4}\right)$. Filtration and removal of the solvent at reduced pressure gave the crude product. Purification by column chromatography (ethyl acetate/heptane 1:4) afforded $518 \mathrm{mg}(78 \%)$ of the title compound as a yellow oil.

${ }^{1} \mathrm{H}$ NMR $\left(400 \mathrm{MHz}, \mathrm{CDCl}_{3}\right) \delta$ 7.76-7.73 (m, 1H), 7.57-7.56 (m, 1H), 7.50-7.83 (m, 5H), $3.54(\mathrm{~s}$, $3 \mathrm{H}), 3.33(\mathrm{~s}, 3 \mathrm{H}) ;{ }^{13} \mathrm{C} \mathrm{NMR}\left(400 \mathrm{MHz}, \mathrm{CDCl}_{3}\right) \delta 168.5,156.0,146.0,138.4,137.9,135.7,133.1$, 132.6, 132.3, 130.4, 130.2, 129.1, 127.2, 125.7, 61.5, 33.8; HRMS (Ion Mode: FAB ${ }^{+}$) $m / z$ [M+H'] Calcd for $\mathrm{C}_{16} \mathrm{H}_{13} \mathrm{ClN}_{2} \mathrm{O}_{2} \mathrm{~S}, 333.0464$; Found, 333.0467.

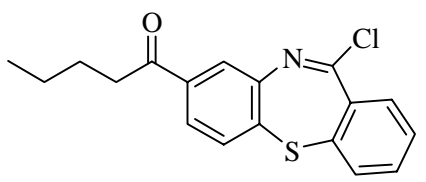

1-(11-Chloro-dibenzo [b,f] $[1,4]$ thiazepine-8-yl)-pentan-1-one (19): Butylmagnesium chloride $(0.10 \mathrm{ml}, 0.2 \mathrm{mmol})$ was added to a solution of 11-chloro-dibenzo[b,f][1,4]thiazepine-8-carboxylic acid methoxymethyl-amide (34 $\mathrm{mg}, 0.10 \mathrm{mmol})$ in dry THF $(2 \mathrm{ml})$. The resulting reaction mixture was stirred at room temperature for 1 hour and then quenched with saturated aqueous $\mathrm{NH}_{4} \mathrm{Cl}(0.2 \mathrm{ml})$ and diluted with $\mathrm{Et}_{2} \mathrm{O}(15 \mathrm{ml})$. The organic phase was washed with water, brine and dried $\left(\mathrm{Na}_{2} \mathrm{SO}_{4}\right)$. Filtration and removal of the solvent at reduced pressure gave the crude product. Purification by column chromatography (ethyl acetate/heptane 1:5) afforded $26 \mathrm{mg}(81 \%)$ of the title compound as a colorless oil.

${ }^{1} \mathrm{H}$ NMR $\left(400 \mathrm{MHz}, \mathrm{CDCl}_{3}\right) \delta 7.82(\mathrm{~d}, 1 \mathrm{H}, J=1.6 \mathrm{~Hz}), 7.77-7.74(\mathrm{~m}, 2 \mathrm{H}), 7.53(\mathrm{~d}, 1 \mathrm{H}, J=8.4 \mathrm{~Hz})$, 7.47-7.39 (m, 3H), $2.90(\mathrm{t}, 2 \mathrm{H}, J=7.2 \mathrm{~Hz}), 1.68$ (quintet, $2 \mathrm{H}, J=7.2 \mathrm{~Hz}), 1.37$ (sextet , $2 \mathrm{H}, J=$ $7.2 \mathrm{~Hz}), 0.93(\mathrm{t}, 3 \mathrm{H}, \mathrm{J}=7.2 \mathrm{~Hz}) ;{ }^{13} \mathrm{C} \mathrm{NMR}\left(100 \mathrm{MHz}, \mathrm{CDCl}_{3}\right): \delta 199.5,156.2,146.4,138.3,138.1$, 137.8, 133.2, 133.1(2), 132,5, 1302, 129.2, 126.6, 125.8, 38.7, 26.5, 22.6, 14.1.; HRMS (Ion Mode: $\left.\mathrm{FAB}^{+}\right) \mathrm{m} / z\left[\mathrm{M}+\mathrm{H}^{+}\right]$Calcd for $\mathrm{C}_{18} \mathrm{H}_{16} \mathrm{ClNOS}$, 330.0719; Found, 330.0718.

\section{A typical procedure for the cross-coupling reactions (table 1).}

A flame-dried $10 \mathrm{ml}$ flask was charged under argon with the imidoyl chloride $(0.20 \mathrm{mmol})$, $\mathrm{Fe}(\mathrm{acac})_{3}(0.01 \mathrm{mmol})$ in dry THF $(2 \mathrm{ml})$ and NMP $(0.2 \mathrm{ml})$. A solution of butylmagnesium chloride $(0.40 \mathrm{mmol})$ was then slowly added to the resulting red solution, causing an immediate color change to dark brown. The resulting mixture was stirred for $5 \mathrm{~min}$ at room temperature and 
the reaction was then quenched upon the addition of saturated aqueous $\mathrm{NH}_{4} \mathrm{Cl}(0.2 \mathrm{ml})$ and diluted with $\mathrm{Et}_{2} \mathrm{O}(25 \mathrm{ml})$. The organic phase was washed with water, brine and dried $\left(\mathrm{Na}_{2} \mathrm{SO}_{4}\right)$. Filtration, removal of the solvent at reduced pressure gave the crude product.

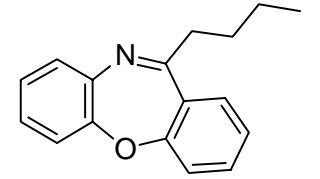

11-Butyl-dibenzo[b,f] $][1,4]$ oxazepine (2): The reaction was performed according to the typical procedure using 11-chloro-dibenzo[b,f][1,4]oxazepine (46 mg, $0.20 \mathrm{mmol}$ ). Purification by column chromatography (ethyl acetate/heptane 1:4) afforded $48 \mathrm{mg}(96 \%)$ of the title compound as a yellow oil.

${ }^{1} \mathrm{H}$ NMR $\left(400 \mathrm{MHz}, \mathrm{CDCl}_{3}\right) \delta$ 7.44-7.41 (m, 2H), 7.30-7.26 (m, 1H), 7.22-7.18 (m, 2H), 7.16-7.13 $(\mathrm{m}, 3 \mathrm{H}), 2.93(\mathrm{t}, 2 \mathrm{H}, J=7.2 \mathrm{~Hz}), 1.71$ (quintet, $2 \mathrm{H}, J=7.6 \mathrm{~Hz}), 1.46(\mathrm{~m}, 2 \mathrm{H}), 0.99(\mathrm{t}, 3 \mathrm{H}, J=$ 7.2Hz); ${ }^{13} \mathrm{C}$ NMR $\left(100 \mathrm{MHz}, \mathrm{CDCl}_{3}\right) \delta 171.2,161.7,152.8,141.0,132.7,128.7,128.4,127.9$, 127.2, 125.7, 125.3, 121.1, 120.8, 40.2, 29.9, 22.7, 14.2; HRMS (Ion Mode: $\mathrm{FAB}^{+}$) $\mathrm{m} / z\left[\mathrm{M}+\mathrm{H}^{+}\right]$ Calcd for $\mathrm{C}_{17} \mathrm{H}_{17} \mathrm{NO}, 252.1388$; Found: 252.1387.

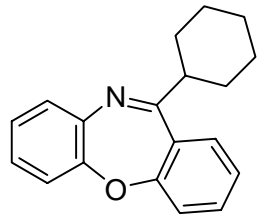

11-Cyclohexyl-dibenzo[b,f] $[1,4]$ oxazepine (3): The reaction was performed according to the typical procedure using 11-chloro-dibenzo[b,f][1,4]oxazepine (46 mg, $0.20 \mathrm{mmol})$ except cyclohexylmagnesium chloride $(0.20 \mathrm{ml}, 0.40 \mathrm{mmol})$ was used in this reaction. Purification by column chromatography (ethyl acetate/heptane 1:4) afforded $52 \mathrm{mg}(93 \%)$ of the title compound as a yellow oil.

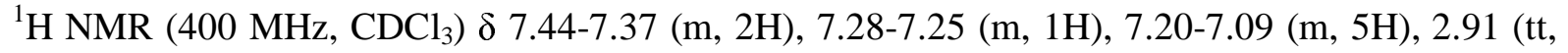
$1 \mathrm{H}, J=14.8,3.2 \mathrm{~Hz}), 2.00-1.97(\mathrm{~m}, 2 \mathrm{H}), 1.89-1.85(\mathrm{~m}, 2 \mathrm{H}), 1.75-1.71(\mathrm{~m}, 1 \mathrm{H}), 1.67-1.55(\mathrm{~m}, 2 \mathrm{H})$, 1.45-1.24 (m, 3H); ${ }^{13} \mathrm{C}$ NMR (100 MHz, $\left.\mathrm{CDCl}_{3}\right): \delta 174.1,162.0,152.7,141.2,132.3,128.9,127.9$ (2C), 126.9, 125.6, 125.2, 120.9, 120.6, 47.0, 31.6, 26.6, 26.4; HRMS (Ion Mode: FAB ${ }^{+}$) $\mathrm{m} / \mathrm{z}$ $\left[\mathrm{M}+\mathrm{H}^{+}\right]$Calcd for $\mathrm{C}_{19} \mathrm{H}_{19} \mathrm{NO}, 278.1545$; Found: 278.1554 .

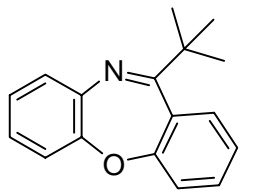

11-Tertbutyl-dibenzo[b,f] $[1,4]$ oxazepine (4): The reaction was performed according to the typical procedure using 11-chloro-dibenzo[b,f][1,4]oxazepine (46 $\mathrm{mg}, 0.20 \mathrm{mmol}$ ), except tert-butylmagnesium chloride ( $2 \mathrm{M}^{\text {in }} \mathrm{Et}_{2} \mathrm{O}, 0.20 \mathrm{ml}, 0.40$ mmol) was used in this reaction. Purification by column chromatography (ethyl acetate/heptane 1:4) afforded $14 \mathrm{mg}(27 \%)$ of the title compound as a yellow oil. 
${ }^{1} \mathrm{H}$ NMR $\left(400 \mathrm{MHz}, \mathrm{CDCl}_{3}\right): \delta 7.53(\mathrm{dd}, 1 \mathrm{H}, J=7.6,1.6 \mathrm{~Hz}), 7.38-7.33(\mathrm{~m}, 1 \mathrm{H}), 7.23-7.20(\mathrm{~m}, 2 \mathrm{H})$, 7.18-7.06 (m, 4H), $1.43(\mathrm{~s}, 9 \mathrm{H}) ;{ }^{13} \mathrm{C}$ NMR (100 MHz, $\left.\mathrm{CDCl}_{3}\right): \delta 177.0,162.2,152.5,141.1,131.5$, 128.1, 127.2, 126.8, 126.4, 125.5, 124.3, 121.0, 120.2,41.5, 30.5; HRMS (Ion Mode: $\mathrm{FAB}^{+}$) m/z $\left[\mathrm{M}+\mathrm{H}^{+}\right]$Calcd for $\mathrm{C}_{17} \mathrm{H}_{17} \mathrm{NO}, 252.1388$; Found, 252.1402.

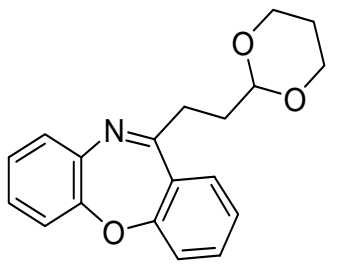

11-(2-[1,3]Dioxane-2-yl-ethyl)-dibenzo[b,f] $[1,4]$ oxazepine $\quad(5): \quad$ The reaction was performed according to the typical procedure using 11-chlorodibenzo[b,f][1,4]oxazepine (46 $\mathrm{mg}, 0.20 \mathrm{mmol}$ ) except 1,3-dioxane-2-ylethyl magnesium bromide $\left(0.5 \mathrm{M}^{\text {in }} \mathrm{Et}_{2} \mathrm{O}, 0.80 \mathrm{ml}, 0.40 \mathrm{mmol}\right)$ was used in this reaction. Purification by column chromatography (ethyl acetate/heptane 1:4) afforded $59 \mathrm{mg}(95 \%)$ of the title compound as a yellow oil.

${ }^{1} \mathrm{H}$ NMR (400 MHz, $\left.\mathrm{CDCl}_{3}\right) \delta 7.47(\mathrm{dd}, 1 \mathrm{H}, J=7.6,1.2 \mathrm{~Hz}), 7.40(\mathrm{dt}, 1 \mathrm{H}, J=8.0,1.6 \mathrm{~Hz}), 7.28-$ $7.25(\mathrm{~m}, 1 \mathrm{H}), 7.20-7.12(\mathrm{~m}, 5 \mathrm{H}), 4.69(\mathrm{t}, 1 \mathrm{H}, J=5.2 \mathrm{~Hz}), 4.10(\mathrm{dd}, 2 \mathrm{H}, J=11.6,4.8 \mathrm{~Hz}), 3.75(\mathrm{dt}$, $2 \mathrm{H}, J=12.0,1,6 \mathrm{~Hz}), 3.03(\mathrm{t}, 2 \mathrm{H}, J=4.8 \mathrm{~Hz}), 2.13-2.02(\mathrm{~m}, 3 \mathrm{H}), 1.35-1.30(\mathrm{~m}, 1 \mathrm{H}) ;{ }^{13} \mathrm{C}$ NMR $(100$ $\left.\mathrm{MHz}, \mathrm{CDCl}_{3}\right) \delta 169.76,161.5,152.7,141.0,132.7,128.9,128.4,128.0,127.2,125.6,125.3,120.9$, 120.7, 101.6, 67.1, 34.1, 32.6, 26.0; HRMS (Ion Mode: $\mathrm{FAB}^{+}$) $\mathrm{m} / z\left[\mathrm{M}+\mathrm{H}^{+}\right]$Calcd for $\mathrm{C}_{19} \mathrm{H}_{19} \mathrm{NO}_{3}$ : 310.1443; Found: 310.1433.

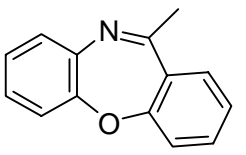

11-Methyl-dibenzo[b,f][1,4]oxazepine (6): The reaction was performed according to the typical procedure using 11-chloro-dibenzo[b,f][1,4] oxazepine (46 $\mathrm{mg}, 0.20 \mathrm{mmol}$ ) except trimethylsilylmethylmagnesium chloride ( $2 \mathrm{M}$ in $\mathrm{Et}_{2} \mathrm{O}$, $0.20 \mathrm{ml}, 0.40 \mathrm{mmol}$ ) was used in this reaction. Purification by column chromatography (ethyl acetate/heptane 1:4) afforded $30 \mathrm{mg}(72 \%)$ of the title compound as a yellow oil.

${ }^{1} \mathrm{H}$ NMR $\left(400 \mathrm{MHz}, \mathrm{CDCl}_{3}\right) \delta$ 7.45-7.40 (m, 2H), 7.29-7.26 (m, 1H), 7.22-7.14 (m, 5H), $2.65(\mathrm{~s}$, $3 \mathrm{H}) ;{ }^{13} \mathrm{C} \mathrm{NMR}\left(100 \mathrm{MHz}, \mathrm{CDCl}_{3}\right) \delta 167.5,161.1,152.7,140.9,132.9,129.3,128.7,127.9,127.4$, 125.7, 125.2, 121.0, 120.8, 27.8; HRMS (Ion Mode: $\mathrm{FAB}^{+}$) $\mathrm{m} / z .\left[\mathrm{M}+\mathrm{H}^{+}\right]$Calcd for $\mathrm{C}_{14} \mathrm{H}_{11} \mathrm{NO}$, 210.0919; Found: 210.0925.

11-Methyl-dibenzo $[$ b,f] $[1,4]$ oxazepine (6): The reaction was performed according to the typical procedure using 11-chloro-dibenzo $[\mathrm{b}, \mathrm{f}][1,4]$ oxazepine $(46 \mathrm{mg}, 0.20 \mathrm{mmol})$ except methylmagnesium chloride ( $1 \mathrm{M}$ in THF, $0.40 \mathrm{ml}, 0.40 \mathrm{mmol}$ ) was used in this reaction. ${ }^{1} \mathrm{H}-\mathrm{NMR}$ 
yield based on toluen as an internal standard showed 11-methyl-dibenzo[b,f][1,4]oxazepine in $17 \%$ yield.

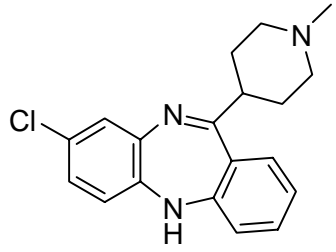

\section{8-Chloro-11-(1-methyl-piperidine-4-yl)-5H-dibenzo $[\mathrm{b}, \mathrm{e}][1,4]$ diazepine}

(11): The reaction was performed according to the typical procedure using 8,11-dichloro- 5H-dibenzo[b,e]-1,4-diazepine (53 mg, $0.2 \mathrm{mmol}$ ) except that 4-methylpiperidinemagnesium chloride (1 M in THF, $0.40 \mathrm{ml}, 0.40 \mathrm{mmol}$ ) was used in this reaction. Purification by column chromatography (ethyl acetate/heptane/MeOH/Et ${ }_{3} \mathrm{~N}$ 2:1:5\%:1\%) afforded $53 \mathrm{mg}(82 \%)$ of the title compound as a yellow oil.

${ }^{1} \mathrm{H}$ NMR (400 MHz, methanol-d $\left.{ }_{4}\right) \delta 7.32$ (dd, $\left.1 \mathrm{H}, J=7.6,1.2 \mathrm{~Hz}\right), 7.24-7.22(\mathrm{~m}, 1 \mathrm{H}), 7.00-6.96$ (m, $2 \mathrm{H}), 6.93(\mathrm{dd}, 1 \mathrm{H}, J=8.4,2.4 \mathrm{~Hz}), 6.83(\mathrm{dd}, 1 \mathrm{H}, J=8.0,1.2 \mathrm{~Hz}), 6.75(\mathrm{~d}, 1 \mathrm{H}, J=8.4 \mathrm{~Hz}), 6.64(\mathrm{br} \mathrm{s}$, $1 \mathrm{H}), 2.96-2.92(\mathrm{~m}, 2 \mathrm{H}), 2.87-2.81(\mathrm{~m}, 1 \mathrm{H}), 2.28(\mathrm{~s}, 3 \mathrm{H}), 2.18-2.11(\mathrm{~m}, 2 \mathrm{H}), 1.91-1.83(\mathrm{~m}, 4 \mathrm{H}) ;{ }^{13} \mathrm{C}$ NMR (100 MHz, methanol-d $\left.\mathrm{d}_{4}\right) \delta 176.7,155.6,143.0,142.2,131.6,128.3,128.3,128.1,127.0$, 125.7, 122.8, 120.6, 119.5, 55.3, 45.1, 44.2, 30.0; HRMS (Ion Mode: FAB ${ }^{+}$) $m / z\left[\mathrm{M}+\mathrm{H}^{+}\right]$Calcd for $\mathrm{C}_{19} \mathrm{H}_{20} \mathrm{ClN}_{3}, 326.1424$; Found, 326.1424.

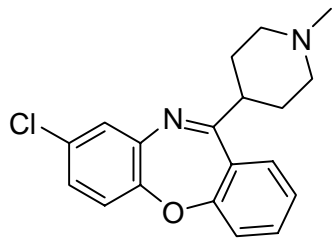

\section{8-Chloro-11-(1-methyl-piperidine-4-yl)-5H-dibenzo [b,f][1,4] oxazepine}

(12): The reaction was performed according to the typical procedure using 8,11-dichlorodibenzo [b,f] [1,4] oxazepine $(53 \mathrm{mg}, 0.20 \mathrm{mmol})$ except that 4-methylpiperidinemagnesium chloride (1 M THF, $0.40 \mathrm{ml}, 0.40 \mathrm{mmol}$ ) was used in this reaction. Purification by column chromatography (ethyl acetate/heptane/ $\mathrm{MeOH} / \mathrm{Et}_{3} \mathrm{~N}$ 2:1:5\%:1\%) afforded $46 \mathrm{mg}(71 \%)$ of the title compound as a yellow oil.

${ }^{1} \mathrm{H}$ NMR $\left(400 \mathrm{MHz}, \mathrm{CDCl}_{3}\right): \delta$ 7.44-7.41 (m, 2H), 7.25-7.15 (m, 2H), 7.17-7.15 (m, 1H), 7.08-7.02 (m, 2H), 2.97-2.94 (m, 2H), 2.90-2.87 (m, 1H), 2.31 (s, 3H), 2.10-2.04 (m, 2H), 1.95-1.91 (m, 4H); ${ }^{13} \mathrm{C}$ NMR $\left(100 \mathrm{MHz}, \mathrm{CDCl}_{3}\right): \delta 173.5,161,5,151,0,141.8,132.5,130.4,128.0,127.6,127.5$, 126.5, 125.3, 121.4, 120.8, 55.8, 46.5, 44.1, 30.5; HRMS (Ion Mode: FAB ${ }^{+}$) $m / z\left[\mathrm{M}+\mathrm{H}^{+}\right]$Calcd for $\mathrm{C}_{19} \mathrm{H}_{19} \mathrm{ClN}_{2} \mathrm{O}, 327.1264$; Found, 327.1273.

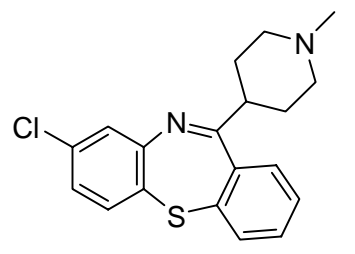

8-Chloro-11-(1-methyl-piperidine-4-yl)-5H-dibenzo thiazepine (13): The reaction was performed according to the typical 
procedure using 8,11-dichloro-dibenzo[b,f][1,4]thiazepine (56 $\mathrm{mg}, 0.20 \mathrm{mmol}$ ) except that 4methylpiperidinemagnesium chloride ( $1 \mathrm{M}$ in THF, $0.40 \mathrm{ml}, 0.40 \mathrm{mmol}$ ) was used in this reaction. Purification by column chromatography (ethyl acetate/heptane/MeOH/Et ${ }_{3} \mathrm{~N}$ 2:1:5\%:1\%) afforded $59 \mathrm{mg}(86 \%)$ of the title compound as a yellow oil.

${ }^{1} \mathrm{H}$ NMR (400 MHz, $\left.\mathrm{CDCl}_{3}\right): \delta{ }^{1} \mathrm{H}$ NMR (400 MHz, $\left.\mathrm{CDCl}_{3}\right): \delta$ 7.44-7.42 (m, 1H), 7.35-7.30 (m, 4H), $7.16(\mathrm{~d}, 1 \mathrm{H}, J=2.4 \mathrm{~Hz}), 6.97(\mathrm{dd}, 1 \mathrm{H}, J=8.4,2.4 \mathrm{~Hz}), 3.02-2.99(\mathrm{~m}, 1 \mathrm{H}), 2.86-2.83(\mathrm{~m}, 2 \mathrm{H})$, $2.29(\mathrm{~s}, 3 \mathrm{H}), 2.11-2.09(\mathrm{~m}, 3 \mathrm{H}), 2.03-1.96(\mathrm{~m}, 1 \mathrm{H}), 1.71-1.65(\mathrm{~m}, 2 \mathrm{H}) ;{ }^{13} \mathrm{C} \mathrm{NMR}(100 \mathrm{MHz}$, $\left.\mathrm{CDCl}_{3}\right): \delta 176.3,149.9,140.8,138.7,134.9,133.3,132,0,130.6,128.8,127.4,127.3,125.2(2 \mathrm{C})$, 56.2, 55.6, 46.6, 46.3, 31.6, 29.2; HRMS (Ion Mode: $\mathrm{FAB}^{+}$) $\mathrm{m} / \mathrm{z}$ [ $\left[\mathrm{M}+\mathrm{H}^{+}\right]$Calcd for $\mathrm{C}_{19} \mathrm{H}_{19} \mathrm{ClN}_{2} \mathrm{~S}$, 343.1036; Found, 343.1037.

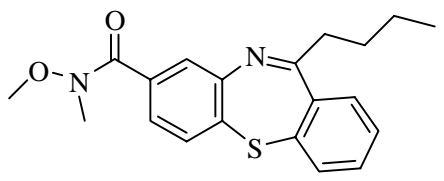

11-butyl-dibenzo[b,f][1,4]thiazepine-8-carboxylic acid methoxymethyl-amide (17): The reaction was performed according to the typical procedure using 11-chloro-dibenzo $[\mathrm{b}, \mathrm{f}][1,4]$ thiazepine-8carboxylic acid methoxy-methyl-amide (62 $\mathrm{mg}, 0.19 \mathrm{mmol})$. Purification by column chromatography (ethyl acetate/heptane 1:1) afforded $47 \mathrm{mg}(70 \%)$ of the title compound as a yellow oil.

${ }^{1} \mathrm{H}$ NMR (400 MHz, $\left.\mathrm{CDCl}_{3}\right): \delta$ 7.45-7.42 (m, 3H), 7.39-7.29 (m, 4H), $3.54(\mathrm{~s}, 3 \mathrm{H}), 3.32(\mathrm{~s}, 3 \mathrm{H})$, 3.01-2.82 (m, 2H), 1.69-1.59 (m, 2H), 1.51-1.41 (m, 2H), $0.92(\mathrm{t}, 3 \mathrm{H}, J=7.2 \mathrm{~Hz}) ;{ }^{13} \mathrm{C}$ NMR $(100$ $\left.\mathrm{MHz}, \mathrm{CDCl}_{3}\right): \delta 174.4,169.2,148.7,140.0,139.0,135.2,132.2,132.1,131.6,130.8,128.7,127.9$, 125.1, 124.9, 61.4, 42.2, 34.1, 29.6, 22.7, 14.1; HRMS (Ion Mode: FAB ${ }^{+}$) $\mathrm{m} / z\left[\mathrm{M}+\mathrm{H}^{+}\right]$Calcd for $\mathrm{C}_{20} \mathrm{H}_{22} \mathrm{~N}_{2} \mathrm{O}_{2} \mathrm{~S}, 355,1480$; Found, 355.77 .

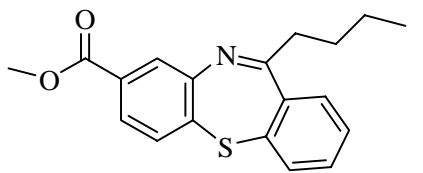

11-Butyl-dibenzo[b,f] $][1,4]$ thiazepine-8-carboxylic acid methyl ester (15): The reaction was performed according to the typical procedure using 11-chloro-dibenzo[b,f][1,4]thiazepine-8-carboxylic acid methyl ester $(152 \mathrm{mg}, 0.50 \mathrm{mmol})$. Purification by column chromatography (ethyl acetate/heptane 1:5) afforded $144 \mathrm{mg}(89 \%)$ of the title compound as a yellow oil. 
${ }^{1} \mathrm{H}$ NMR $\left(400 \mathrm{MHz}, \mathrm{CDCl}_{3}\right) \delta 7.84(\mathrm{~d}, 1 \mathrm{H}, J=1.6 \mathrm{~Hz}), 7.68(\mathrm{dd}, 1 \mathrm{H}, J=8.0,1.6 \mathrm{~Hz}), 7.74-7.43(\mathrm{~m}$, 2H), 7.40-7.31 (m, 3H), $3.87(\mathrm{~s}, 3 \mathrm{H}), 3.02-2.85(\mathrm{~m}, 2 \mathrm{H}), 1.74-1.58(\mathrm{~m}, 2 \mathrm{H}), 1.55-1.41(\mathrm{~m}, 2 \mathrm{H}), 0.93$ $(\mathrm{t}, 3 \mathrm{H}, J=7.2 \mathrm{~Hz}) ;{ }^{13} \mathrm{C} \mathrm{NMR}\left(100 \mathrm{MHz}, \mathrm{CDCl}_{3}\right) \delta 174.5,166.7,148.8,139.7,139.0,134.4,132.5$, 132.3, 131.1, 130.9, 128.9, 127.9, 126.6, 126.1, 52.4, 42.2, 29.5, 22.7, 14.2; HRMS (Ion Mode: $\left.\mathrm{FAB}^{+}\right) m / z\left[\mathrm{M}+\mathrm{H}^{+}\right]$Calcd for $\mathrm{C}_{19} \mathrm{H}_{19} \mathrm{NO}_{2} \mathrm{~S}, 325.1136$; Found: 325.1136 .

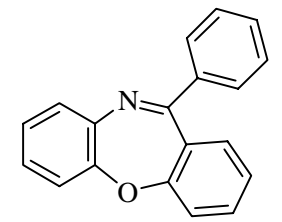

11-Phenyl-dibenzo[b,f][1,4]oxazepine (7): The reaction was performed according to the typical procedure using 11-chloro-dibenzo[b,f][1,4]oxazepine (46 mg, $0.20 \mathrm{mmol}$ ) except that an excess (6 equivalents) of phenylmagnesium chloride $(0.60 \mathrm{ml}, 1.2 \mathrm{mmol})$ was used and the reaction time (30 $\mathrm{min})$ was extended. Purification by column chromatography (ethyl acetate/heptane 1:4) afforded $30 \mathrm{mg}$ (55\%) of the title compound as a colorless oil.

${ }^{1} \mathrm{H}$ NMR (400 MHz, $\left.\mathrm{CDCl}_{3}\right)$ $\delta$ 7.84-7.81 (m, 2H), 7.51-7.42 (m, 5H), 7.28-7.27 (m, 1H), 7.23-7.13 $(\mathrm{m}, 5 \mathrm{H}) ;{ }^{13} \mathrm{C}$ NMR $\left(100 \mathrm{MHz}, \mathrm{CDCl}_{3}\right) \delta 167.2,162.2,152.6,141.0,140.3,133.1,131.4,130.5$, 129.8, 128.4, 128.3, 127.7, 127.6, 125.7, 124.6, 121.1, 120.8; HRMS (Ion Mode: FAB ${ }^{+}$) m/z $\left[\mathrm{M}+\mathrm{H}^{+}\right]$Calcd for $\mathrm{C}_{19} \mathrm{H}_{13} \mathrm{NO}: 272.1075$; Found: 272.1067 .

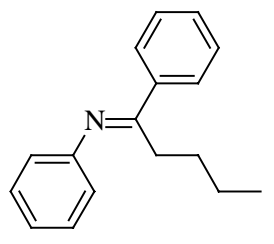

Phenyl-[1-phenyl-pent-(E/Z)-ylidene]-amine (21): A mixture of Benzanilide (50 mg, $0.25 \mathrm{mmol})$ and $\mathrm{SOCl}_{2}(5 \mathrm{ml})$ was heated at $80{ }^{\circ} \mathrm{C}$ for 1 hour. The excess of $\mathrm{SOCl}_{2}$ was removed at reduced pressure and the obtained imidoyl chloride was used in the next step without purification. The cross-coupling reaction was performed according to the typical procedure. Purification by column chromatography (ethyl acetate/heptane 1:10) afforded $43 \mathrm{mg}(72 \%)$ of the title compound (E:Z;7:1) as a colourless oil. 